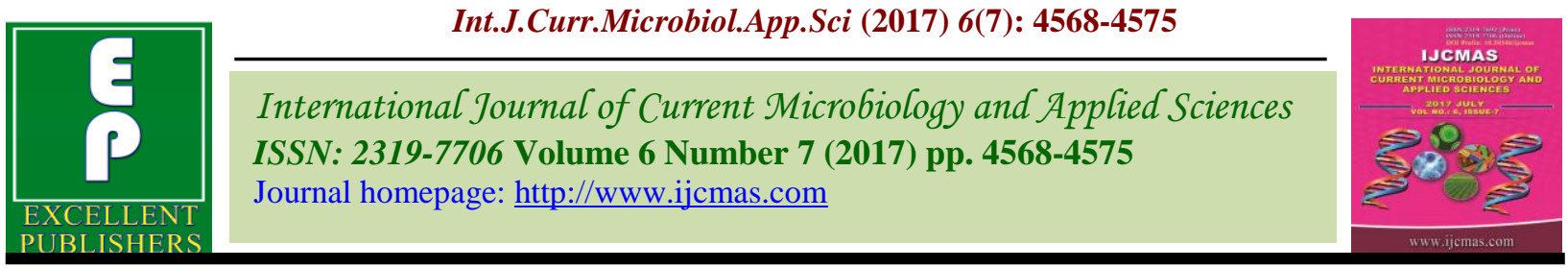

Original Research Article

https://doi.org/10.20546/ijcmas.2017.607.477

\title{
Analysis of Physico-Genetic Traits for Drought Tolerance in Maize (Zea mays L.)
}

\author{
N. Kumari Vinodhana ${ }^{1 *}$ and K. N. Ganesan ${ }^{2}$ \\ ${ }^{1}$ Maize Research Station, TNAU, Vagarai, Tamil Nadu, India \\ ${ }^{2}$ Centre for Plant Breeding and Genetics, TNAU, Coimbatore, Tamil Nadu, India \\ *Corresponding author
}

\section{A B S T R A C T}

Development of drought tolerant lines becomes increasingly more important in maize. Therefore, an investigation was undertaken with six lines VIM 57 (L1), VIM 61 (L2), UMI 1200 (L3), VIM 244 (L4), VIM 15 (L5), VIM 108 (L6) and four testers VIM 236 (T1), VIM 93 (T2), VIM 418 (T3), VIM 153 (T4) which were crossed in a Line x Tester mating

\section{Keywords}

Maize, Heterosis, Combining ability, Drought, Anthesis Silking Interval, Leaf rolling, Relative water content

Article Info

Accepted:

20 June 2017

Available Online:

10 July 2017 design to synthesize twenty four hybrids and were evaluated under contrasting soil moisture regimes to identify the potential parents, superior cross combinations and to formulate the breeding strategies for yield improvement in maize. The selection indices of drought included Anthesis Silking Interval (days), Relative Water Content (\%), Leaf Rolling, Root dry weight (g), Root volume $\left(\mathrm{cm}^{3}\right)$ and Drought Recovery Rate. Results of the study revealed significant differences among the hybrids for all measured traits. The relatively smaller proportion of GCA to SCA ratio indicated the predominance of nonadditive genetic effects for all the traits under study. Under induced moisture stress conditions, the parents L5 (Plant height, ASI, RWC), L3 (Cob weight and Grain yield), L4, L1 (Cob length) and T4 (Days to flowering, Number of kernels per row, Leaf rolling and RWC) had desirable per se and gca effects. On the basis of per se, sca and standard heterosis, under induced moisture stress, the hybrids L2xT1 (VIM 61 x VIM 236), L3xT2 (UMI 1200 x VIM 93), L3xT4 (UMI 1200 x VIM 153), L4xT4 (VIM 244 x VIM153) and L6xT3 (VIM108 x VIM 418) were found to be desirable for yield/plant and most yield components under drought. The hybrid L3 x T4 (UMI 1200 x VIM 153) recorded positively significant values for grain yield and considered as the best hybrid for both the conditions. The study revealed that the identified hybrids showed desirable heterotic levels for yield and drought parameters that are desirable in areas with marginal rainfalls and could be utilized in maize breeding programs.

\section{Introduction}

Maize (Zea mays L.) one of the most important food crops in the world, is very sensitive to drought, especially during flowering, pollination and embryo enlargement. Improving drought tolerance in maize has become one of the top priorities in maize breeding programs. The strength of any breeding programme depends on the genetic variability in the base populations and development of superior lines / inbreds. Apart from selection of superior lines and their combining ability, placing them in welldefined heterotic groups is very much essential to increase the probability of success in heterosis breeding. Therefore, the study was conducted to estimate the general combining ability effect of parents, specific combining effect of hybrids and to determine 
the high parent heterosis existing among the traits for drought tolerance.

\section{Materials and Methods}

The experiment was conducted at Maize Research Station, TNAU, Vagarai during 2014-15 and the material for the study comprised of six lines VIM 57 (L1), VIM 61 (L2), UMI 1200 (L3), VIM 244 (L4), VIM 15 (L5), VIM 108 (L6) and four testers VIM 236 (T1), VIM 93 (T2), VIM 418 (T3), VIM 153 (T4) which were crossed in a Line $\mathrm{x}$ Tester mating design to synthesize twenty four hybrids. The hybrids along with the parents were evaluated in a randomized block design under irrigated and induced stress conditions (from a week before flowering, for twenty five days) in two replications. Observation were recorded for the biometrical traits viz., Plant height $(\mathrm{cm})$, Days to $50 \%$ tasseling, Days to $50 \%$ silking, Cob length $(\mathrm{cm}), \mathrm{Cob}$ weight (g), Number of kernel rows, Number of kernels per row, 100 kernel weight $(\mathrm{g})$, Grain yield per plant (g) and Harvest Index. The selection indices of drought recorded included Anthesis Silking Interval, Relative Water Content (\%), Leaf Rolling, Root dry weight $(\mathrm{g})$, Root volume $\left(\mathrm{cm}^{3}\right)$ and Drought Recovery Rate are furnished below.

\section{Anthesis and Silking Interval (ASI)}

Anthesis and silking interval is measured as difference between $50 \%$ tassels has extruded the anther (AD) and $50 \%$ of cobs (SD) have emerged silk in days (CIMMYT 2000).

$\mathrm{ASI}=\mathrm{SD}-\mathrm{AD}$

\section{Relative Water Content (RWC)}

The relative water content of leaf was worked out using a formula proposed by Barrs and Weatherley (1962) and expressed in percentage
RWC $=\frac{\text { Fresh weight }- \text { Dry weight }}{\text { Turgid weight }- \text { Dry weight }}$

\section{Leaf Rolling (LR)}

The scales for leaf rolling were observed on five top most leaves of selected ten plants at $70 \%$ RWC. The scales followed are according to CIMMYT 2000.

\section{Drought Recovery Rate (DRR)}

The scales for DRR were observed on whole population after reirrigation at $70 \%$ RWC. The scales followed are according to standard evaluation systems for rice (IRRI 1996).

\section{Root Volume $\left(\mathrm{cm}^{3}\right)$}

Plants were uprooted at maturity, roots were cut and washed and the volume was recorded adopting water displacement method and expressed in cubic centimeter.

\section{Root Dry Weight (g)}

Selected plants were uprooted and the roots were cut from the stem, washed, dried in hot air oven at $80^{\circ} \mathrm{C}$ for 48 hours, weighed and recorded in grams.

The data of all the traits recorded were subjected to analysis of variance appropriate for Line $\mathrm{x}$ Tester crossing design in individual environments as suggested by Kempthorne (1957).

\section{Results and Discussion}

The analysis of variance of RBD revealed significant differences among the parents and hybrids for all the characters under study indicating the existence of wide variability among the genotypes. The parents six lines and four testers involved in the investigation 
were evaluated based on mean performance and $g c a$ effects. Parents with high mean values and gca effects are preferred for using in hybridization programme as they are expected to produce desirable segregants. In this study, under irrigated condition, the parents $\mathrm{L}_{1}$ (100 kernel weight, number of kernels per row), $\mathrm{L}_{2}$ (plant height) $\mathrm{L}_{5}$ (days to $50 \%$ silking), $\mathrm{L}_{4}$ and $\mathrm{T}_{2}$ (days to $50 \%$ tasseling) and $\mathrm{T}_{3}$ (plant height, number of kernels per row, harvest index) and under induced moisture stress conditions, the parents L5 and L6 (Plant height, Anthesis silking interval, Relative Water Content), L3 (Cob weight and Grain yield), L4, L1 (Cob length) and T4 (Days to flowering, Number of kernels per row, Leaf rolling and RWC) were found to have desirable per se and gca effects (Table 1, 2).

Typical visual symptoms of drought stress in maize are a change in color from green to green-gray and rolling of the lower leaves followed by those in the upper canopy. At the same time stomatal closure results in reduced photosynthesis and slow growth. Events at flowering play a critically important part in yield stability under drought. When stress coincides with the 7-10 day period prior to flowering, ear growth will slow more than tassel growth and there is a delay in silk emergence relative to pollen shed, giving rise to an interval between anther extrusion and silk exposure. Partitioning of assimilate to the developing ear directly affects ovule growth at flowering and the Anthesis Silking Interval (ASI). This ASI can be used to predict drought-induced yield reduction (Maazou et al., 2016). In this study, $\mathrm{L}_{5}$ and $\mathrm{L}_{6}$ among lines were the best general combiners for ASI.

The mean values of lines for ASI ranged from $3.20\left(\mathrm{~L}_{1}\right)$ to $7.10\left(\mathrm{~L}_{4}\right)$ while in testers it ranged from $2.50\left(\mathrm{~T}_{2}\right)$ to $6.20\left(\mathrm{~T}_{3}\right)$ and among the hybrids ASI ranged from $1.30\left(\mathrm{~L}_{6} \times \mathrm{T}_{4}\right)$ to 7.95 days $\left(\mathrm{L}_{4} \times \mathrm{T}_{3}\right)$ (Table 1,2$)$. Low values of ASI are an indication of synchronism in the flowering time, which means an adaptation for better yield under drought condition, as a partial consequence of a high water potential during the flowering time. According to Bolanos and Edmeades (1996), for maize associated with grain yield under stress, in descending order of importance have been kernel number (barrenness; kernel number per ear), a short ASI; increased leaf erectness; reduced canopy temperature; and increased visual stay green and kernel weight.

Kernel number is largely determined at flowering. The slower growth of ears under drought sometimes means that pollen is shed before silks emerge, and in very uniform hybrids with small tassels pollination may fail because of pollen shortage. Generally however, the slow growth of the ear prior to silking is reflected in slow growth and small size of ovules, weak silk growth and a failure to set grain even when pollinated with adequate amounts of fresh pollen. The numbers of kernels set filled under drought stress accounts for most of the variation in maize grain yield under drought (Bruce et al., 2002), and directly affects HI. Highly significant per se performance for harvest index was reported in the lines $\mathrm{L}_{1}, \mathrm{~L}_{4}$ and $\mathrm{L}_{5}$ whereas among the testers $\mathrm{T}_{1}$ recorded significant value when compared with their respective mean.

Severe stress at flowering may lead to the complete abortion of ears and the plant becomes barren. Drought-affected ears typically have fewer kernels that will be poorly filled if drought extends throughout grain filling (Edmeades et al., 2000). The mean values of lines for grain yield per plant ranged from $37.97 \mathrm{~g}\left(\mathrm{~L}_{2}\right)$ to $77.06 \mathrm{~g}\left(\mathrm{~L}_{5}\right)$ and in testers, it ranged from $34.95 \mathrm{~g}\left(\mathrm{~T}_{4}\right)$ to 65.41 $\mathrm{g}\left(\mathrm{T}_{3}\right)$. Based on per se, the lines $\mathrm{L}_{3}, \mathrm{~L}_{4}, \mathrm{~L}_{5}$ and the testers $\mathrm{T}_{3}$ recorded highest significant value as compared to their respective means 
(Table 1, 2). Nine hybrids showed significantly higher values than the grand mean. Considering both per se and gca together $\mathrm{L}_{3}$ could be chosen for improving this character. Moser et al., (2006) studied the effect of water stress on the yield of four maize cultivars and reported that the number of kernel rows, number of kernels per row and 1000 kernel weight was minimized under water stress condition. Olaoye et al., (2009) evaluated fourteen corn varieties under normal condition and water stress imposed by the withdrawl of number of irrigations from preanthesis to maturity. Water stress minimized the grain yield $53 \%$ and upto $22 \%$ reduction in number of ears per plant.

High root volume was an indication of the greater ability to permeat a larger volume of soil or to have thicker roots (Ribaut et al.,
2009). In this study, the root volume ranged from $12.57\left(\mathrm{~L}_{1}\right)$ to 32.77 cu.cm $\left(\mathrm{L}_{2}\right)$ among lines and $13.67\left(\mathrm{~T}_{4}\right)$ to 23.32 cu.cm $\left(\mathrm{T}_{3}\right)$ among testers. Two lines, three testers and five hybrids showed more root volume than the mean. The hybrids $\mathrm{L}_{1} \times \mathrm{T}_{1}, \mathrm{~L}_{2} \times \mathrm{T}_{1}, \mathrm{~L}_{3} \times$ $\mathrm{T}_{1}, \mathrm{~L}_{3} \times \mathrm{T}_{2}, \mathrm{~L}_{3} \times \mathrm{T}_{3}, \mathrm{~L}_{3} \times \mathrm{T}_{4}, \mathrm{~L}_{5} \times \mathrm{T}_{1}, \mathrm{~L}_{5} \times \mathrm{T}_{3}$, $\mathrm{L}_{6} \times \mathrm{T}_{1}, \mathrm{~L}_{6} \times \mathrm{T}_{4}$ showed significant positive standard heterosis for root volume. Corn genotypes with low root dry weight are less tolerant to drought stress. Considering both per se and gca effects, $\mathrm{L}_{2}$ could be chosen for improving this trait. The drought recovery score of lines and testers ranged from 3.20 $\left(\mathrm{L}_{3}\right)$ to $8.25\left(\mathrm{~L}_{1}\right)$ and from $3.25\left(\mathrm{~T}_{2}\right)$ to 5.15 $\left(\mathrm{T}_{1}\right)$ respectively. The hybrids $\left(\mathrm{L}_{2} \times \mathrm{T}_{3}, \mathrm{~L}_{6} \times\right.$ $\mathrm{T}_{4}$ ) recorded the lowest drought recovery score of 3.15 and the hybrid $\mathrm{L}_{1} \times \mathrm{T}_{3}$ recorded highest score of 6.20 (Table 1, 2; Fig 1).

Table.1 Mean performance of parents under stress

\begin{tabular}{|c|c|c|c|c|c|c|c|c|}
\hline LINES & $\begin{array}{r}\text { SPY } \\
(\mathrm{g}) \\
\end{array}$ & HI & $\begin{array}{c}\text { ASI } \\
\text { (days) }\end{array}$ & $\mathbf{L R}$ & $\begin{array}{c}\text { RDW } \\
(\mathrm{g})\end{array}$ & $\begin{array}{c}\text { RV } \\
\left(\mathrm{cm}^{3}\right) \\
\end{array}$ & DRR & $\begin{array}{c}\text { RWC } \\
(\%)\end{array}$ \\
\hline $\mathbf{L}_{1}$ & 52.94 & $61.32 *$ & $3.20 *$ & 5.46 & 4.94 & 12.57 & 8.25 & 67.54 \\
\hline $\mathbf{L}_{2}$ & 37.97 & 40.34 & $5.45^{*}$ & $3.26^{*}$ & $7.70 *$ & $32.77 *$ & $4.25 *$ & 64.72 \\
\hline $\mathbf{L}_{3}$ & $61.08 *$ & 44.44 & $6.00 *$ & $2.31 *$ & 4.94 & 15.68 & $3.20 *$ & 67.81 \\
\hline $\mathbf{L}_{4}$ & $71.33^{*}$ & $51.58 *$ & 7.1 & $3.36^{*}$ & $7.03 *$ & $22.51 *$ & $4.20 *$ & 68.34 \\
\hline $\mathbf{L}_{5}$ & $77.06^{*}$ & $62.27 *$ & $4.15^{*}$ & 4.31 & 5.99 & 15.68 & $4.25^{*}$ & $74.54 *$ \\
\hline $\mathbf{L}_{6}$ & 47.11 & 27.95 & $4.65^{*}$ & 4.52 & 5.13 & 17.59 & $4.35^{*}$ & $79.70 *$ \\
\hline Grand mean & 57.91 & 47.98 & 5.09 & 3.87 & 5.95 & 19.47 & 4.75 & 70.44 \\
\hline SED & $\mathbf{0 . 0 7}$ & $\mathbf{0 . 0 7}$ & $\mathbf{0 . 5 7}$ & 0.04 & 0.18 & 0.08 & 0.5 & 0.33 \\
\hline CD 5\% & 0.14 & 0.13 & 1.17 & 0.08 & 0.36 & 0.15 & 1.01 & 0.68 \\
\hline \multicolumn{9}{|l|}{ TESTERS } \\
\hline $\mathbf{T}_{1}$ & 46.01 & $46.33^{*}$ & $2.35 *$ & 5.36 & 5.89 & $22.72 *$ & 5.15 & 74.71 \\
\hline $\mathbf{T}_{2}$ & 38.97 & 33.83 & $2.50^{*}$ & 5.36 & 6.08 & $22.92 *$ & $3.25^{*}$ & $81.55^{*}$ \\
\hline $\mathbf{T}_{\mathbf{3}}$ & $65.41^{*}$ & 30.06 & 6.2 & $3.36^{*}$ & $7.89^{*}$ & $23.32 *$ & $3.30 *$ & 65.78 \\
\hline $\mathbf{T}_{4}$ & 34.95 & 31.38 & $4.05 *$ & $4.41 *$ & $7.03 *$ & 13.67 & $4.25^{*}$ & $75.85 *$ \\
\hline Grand mean & 46.33 & 35.4 & 3.78 & 4.62 & 6.72 & 20.65 & 3.99 & 74.47 \\
\hline SED & 0.05 & 0.05 & 0.47 & $\mathbf{0 . 0 3}$ & 0.14 & 0.06 & 0.4 & 0.27 \\
\hline CD 5\% & 0.11 & 0.11 & 0.95 & 0.07 & 0.29 & 0.13 & 0.82 & 0.56 \\
\hline
\end{tabular}


Table.2 gca effects of parents for component traits of drought under stress condition

\begin{tabular}{|c|c|c|c|c|c|c|c|c|}
\hline Lines & SPY & HI & ASI & LR & RDW & RV & DRR & RWC \\
\hline $\mathbf{L}_{\mathbf{1}}$ & $-13.76^{* *}$ & $-2.20^{* *}$ & -0.35 & $-1.04^{* *}$ & $-0.61^{* *}$ & $-12.99^{* *}$ & 0.05 & $-0.89^{* *}$ \\
\hline $\mathbf{L}_{\mathbf{2}}$ & $-6.38^{* *}$ & $4.07^{* *}$ & $0.95^{*}$ & $-0.30^{* *}$ & $2.22^{* *}$ & $-6.05^{* *}$ & -0.70 & $-1.92^{* *}$ \\
\hline $\mathbf{L}_{\mathbf{3}}$ & $10.93^{* *}$ & $1.56^{* *}$ & 0.67 & $0.83^{* *}$ & $2.79^{* *}$ & $16.64^{* *}$ & -0.22 & $1.79^{* *}$ \\
\hline $\mathbf{L}_{\mathbf{4}}$ & $-6.78^{* *}$ & $-2.58^{* *}$ & $1.78^{* *}$ & $0.28^{* *}$ & $-2.43^{* *}$ & $-11.45^{* *}$ & $1.25^{* *}$ & $-10.70^{* *}$ \\
\hline $\mathbf{L}_{\mathbf{5}}$ & $-2.18^{* *}$ & $-5.50^{* *}$ & $-1.26^{* *}$ & $0.22^{* *}$ & $-0.94^{* *}$ & $-1.98^{* *}$ & 0.30 & $9.07^{* *}$ \\
\hline $\mathbf{L}_{\mathbf{6}}$ & $18.17^{* *}$ & $4.66^{* *}$ & $-1.79^{* *}$ & 0.01 & $-1.03^{* *}$ & $15.83^{* *}$ & -0.67 & $2.65^{* *}$ \\
\hline $\mathbf{S E}$ & $\mathbf{0 . 0 5}$ & $\mathbf{0 . 0 5}$ & $\mathbf{0 . 4 1}$ & $\mathbf{0 . 0 3}$ & $\mathbf{0 . 1 2}$ & $\mathbf{0 . 0 5}$ & $\mathbf{0 . 3 5}$ & $\mathbf{0 . 2 4}$ \\
\hline $\mathbf{T e s t e r s}$ & & & & & & & & \\
\hline $\mathbf{T}_{\mathbf{1}}$ & $2.74^{* *}$ & $2.46^{* *}$ & 0.17 & $0.15^{* *}$ & $2.47^{* *}$ & $12.82^{* *}$ & -0.29 & $0.91^{* *}$ \\
\hline $\mathbf{T}_{\mathbf{2}}$ & $0.93^{* *}$ & $-2.16^{* *}$ & 0.37 & 0.01 & $-2.27^{* *}$ & $-9.19^{* *}$ & 0.18 & $-1.25^{* *}$ \\
\hline $\mathbf{T}_{\mathbf{3}}$ & $-7.24^{* *}$ & $-2.99^{* *}$ & -0.14 & $0.22^{* *}$ & $-0.37^{* *}$ & $4.78^{* *}$ & 0.24 & $-6.47^{* *}$ \\
\hline $\mathbf{T}_{\mathbf{4}}$ & $3.56^{* *}$ & $2.69^{* *}$ & -0.40 & $-0.39^{* *}$ & 0.17 & $-8.40^{* *}$ & -0.13 & $6.80^{* *}$ \\
\hline $\mathbf{S E}$ & $\mathbf{0 . 0 4}$ & $\mathbf{0 . 0 4}$ & $\mathbf{0 . 3 3}$ & $\mathbf{0 . 0 2}$ & $\mathbf{0 . 1 0}$ & $\mathbf{0 . 0 4}$ & $\mathbf{0 . 2 9}$ & $\mathbf{0 . 1 9}$ \\
\hline
\end{tabular}

Table.3 Mean performance of promising hybrids under stress for drought parameters

\begin{tabular}{|c|c|c|c|c|c|c|}
\hline HYBRIDS & ASI & LR & $\begin{array}{c}\text { RDW } \\
(\mathbf{g})\end{array}$ & $\begin{array}{c}\mathbf{R V} \\
\left(\mathbf{c m}^{\mathbf{3}}\right)\end{array}$ & DRR & $\begin{array}{c}\text { RWC } \\
(\boldsymbol{\%})\end{array}$ \\
\hline $\mathbf{L}_{\mathbf{2}} \times \mathbf{T}_{\mathbf{1}}$ & $6.80^{*}$ & 5.36 & $26.60^{*}$ & $45.33^{*}$ & $4.20^{*}$ & 62.05 \\
\hline $\mathbf{L}_{\mathbf{3}} \times \mathbf{T}_{\mathbf{2}}$ & $5.10^{*}$ & 5.67 & $13.40^{*}$ & 36.69 & $4.10^{*}$ & $72.42^{*}$ \\
\hline $\mathbf{L}_{\mathbf{3}} \times \mathbf{T}_{\mathbf{4}}$ & 4.55 & 5.36 & $11.50^{*}$ & 35.68 & $5.20^{*}$ & 69.36 \\
\hline $\mathbf{L}_{\mathbf{4}} \times \mathbf{T}_{\mathbf{4}}$ & $3.65^{*}$ & $4.41^{*}$ & 9.70 & 25.13 & $6.15^{*}$ & $79.75^{*}$ \\
\hline $\mathbf{L}_{\mathbf{6}} \times \mathbf{T}_{\mathbf{3}}$ & $5.56^{*}$ & $4.41^{*}$ & $11.20^{*}$ & 32.67 & $5.30^{*}$ & 69.60 \\
\hline SED & $\mathbf{1 . 1 5}$ & $\mathbf{0 . 0 8}$ & $\mathbf{0 . 3 5}$ & $\mathbf{0 . 1 5}$ & $\mathbf{0 . 9 9}$ & $\mathbf{0 . 6 7}$ \\
\hline CD 5\% & $\mathbf{2 . 3 3}$ & $\mathbf{0 . 1 6}$ & $\mathbf{0 . 7 1}$ & $\mathbf{0 . 3 1}$ & $\mathbf{2 . 0 1}$ & $\mathbf{1 . 3 6}$ \\
\hline
\end{tabular}

Table.4 sca effects and standard heterosis of promising hybrids under stress

\begin{tabular}{|c|c|c|c|c|c|c|c|}
\hline HYBRIDS & ASI & LR & RDW & RV & DRR & RWC & Standard heterosis for yield \\
\hline $\mathbf{L}_{\mathbf{2}} \mathbf{X} \mathbf{T}_{\mathbf{1}}$ & 1.09 & $1.11^{* *}$ & $12.09^{* *}$ & $1.98^{* *}$ & 0.55 & $-5.45^{* *}$ & $10.96^{* *}$ \\
\hline $\mathbf{L}_{\mathbf{3}} \mathbf{X} \mathbf{T}_{\mathbf{2}}$ & -0.52 & $0.43^{* *}$ & $4.44^{* *}$ & $-7.34^{* *}$ & -0.51 & $3.36^{* *}$ & $25.17^{* *}$ \\
\hline $\mathbf{L}_{\mathbf{3}} \mathbf{X} \mathbf{T}_{\mathbf{4}}$ & $2.80^{* *}$ & $0.52^{* *}$ & $2.65^{* *}$ & $-9.13^{* *}$ & 0.91 & $-7.75^{* *}$ & $43.43^{* *}$ \\
\hline $\mathbf{L}_{\mathbf{4}} \mathbf{X ~ T}_{\mathbf{4}}$ & $-2.31^{* *}$ & $0.13^{*}$ & -0.16 & $8.40^{* *}$ & 0.4 & $15.13^{* *}$ & $10.96^{* *}$ \\
\hline $\mathbf{L}_{\mathbf{6}} \mathbf{X ~ T}_{\mathbf{3}}$ & $2.91 * *$ & $-0.22^{* *}$ & 0.24 & $-24.53^{* *}$ & 1.08 & $4.90^{* *}$ & $24.00^{* *}$ \\
\hline
\end{tabular}

\section{Leaf Rolling (LR)}

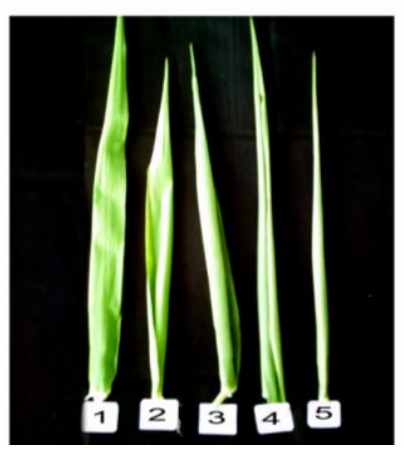

\begin{tabular}{|r|r|}
\hline Scale & Observation \\
\hline 1 & Unrolled, turgid \\
\hline 2 & Leaf rim starts to roll \\
\hline 3 & Leaf has a shape of a V \\
\hline 4 & Rolled leaf rim covers the part of leaf blade \\
\hline 5 & Leaf rolled like onion \\
\hline
\end{tabular}




\section{Drought Recovery Rate (DRR)}

\begin{tabular}{|c|l|}
\hline Scale & \% of plants recovered \\
\hline 1 & $90-100$ \\
\hline 3 & $70-89$ \\
\hline 5 & $40-69$ \\
\hline 7 & $20-39$ \\
\hline 9 & $0-19$ \\
\hline
\end{tabular}

Fig.1 Best hybrid (VIM 61 x VIM 236) for root architecture

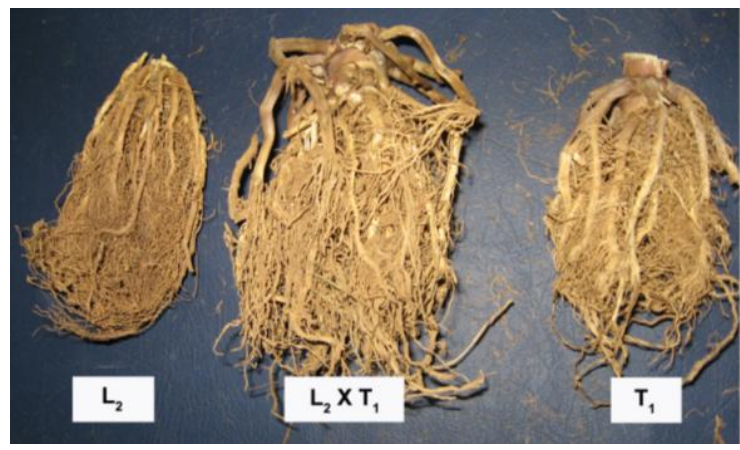

Fig.2 Best hybrid (UMI 1200 X VIM 153) identified under stress condition

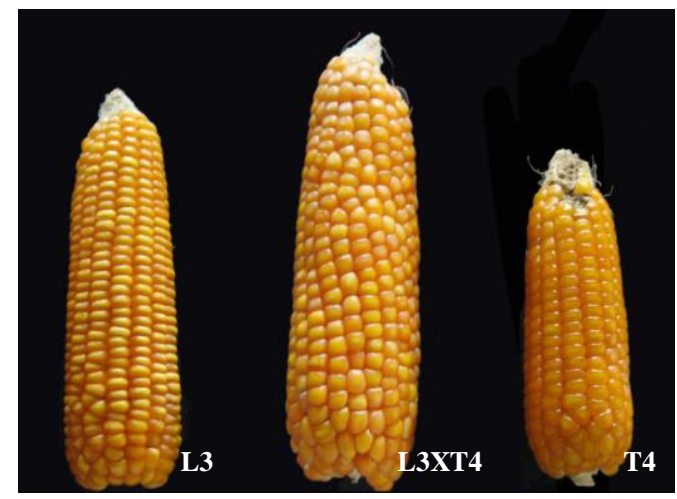

Under moisture stress condition, the hybrids for leaf rolling ranged from $2.21\left(\mathrm{~L}_{1} \times \mathrm{T}_{4}\right)$ to $5.0\left(\mathrm{~L}_{1} \times \mathrm{T}_{3}, \mathrm{~L}_{3} \times \mathrm{T}_{2}\right)$, out of which thirteen hybrids showed significantly less score values (Table 1,3).

Saglam et al., (2014) reported that leaf rolling in the drought tolerant genotype Batem 56-55 occurred later than the drought sensitive genotype Batem 51-52 and the results implied that leaf rolling was an important and necessary mechanism protecting photosynthesis and reducing yield loss under drought stress by maintaining the leaf hydration, preventing loss of the photosynthetic pigments, sustaining the activity of PSII, keeping the stomata open, and conserving the activity of Rubisco.

In this study, the hybrids $\mathrm{L}_{2} \times \mathrm{T}_{2}, \mathrm{~L}_{4} \times \mathrm{T}_{2}$ for plant height, $\mathrm{L}_{4} \times \mathrm{T}_{2}$ for days to $50 \%$ tasseling, $\mathrm{L}_{1} \times \mathrm{T}_{4}, \mathrm{~L}_{3} \times \mathrm{T}_{4}$ for cob weight, $\mathrm{L}_{1}$ $\times \mathrm{T}_{2}, \mathrm{~L}_{5} \times \mathrm{T}_{2}$ for 100 kernel weight, $\mathrm{L}_{1} \times \mathrm{T}_{4}$, $\mathrm{L}_{5} \times \mathrm{T}_{3}$ for number of kernels per row and $\mathrm{L}_{1}$ 
$\times \mathrm{T} 4, \mathrm{~L}_{3} \times \mathrm{T}_{4}$ for grain yield showed desirable gca effects and non-significant sca effects under irrigated condition, while under induced moisture stress condition, the hybrids $\mathrm{L}_{2} \times \mathrm{T}_{1}, \mathrm{~L}_{2} \times \mathrm{T}_{4}$ for plant height, $\mathrm{L}_{6} \times \mathrm{T}_{4}$ for cob length $\mathrm{L}_{1} \times \mathrm{T}_{1}$ for number of kernel rows, showed non-significant sca effect with favourable gca effects of parents (table 3. Hence these hybrids are recommended for recombination breeding. Recombination breeding involves selection of segregants to exploit additive gene effects (Fu et al., 2008). Hybrids with non-significant sca effects having parents possessing significant and desirable gca effects were chosen for recombination breeding as they are likely to throw more recombinants possessing favorable additive genes.

On the basis of per se, sca and standard heterosis under irrigated condition, the hybrid $\mathrm{L}_{2} \times \mathrm{T}_{4}$ was suited to heterosis breeding for cob weight and grain yield, $\mathrm{L}_{2} \times \mathrm{T}_{2}$ for 100 kernel weight, $\mathrm{L}_{1} \times \mathrm{T}_{4}, \mathrm{~L}_{2} \times \mathrm{T}_{3}$ and $\mathrm{L}_{4} \times \mathrm{T}_{3}$ for plant height and number of kernels per row and $\mathrm{L}_{5} \times \mathrm{T}_{4}$ for number of kernel rows. Nouman (2012) evaluated six genotypes by estimating combining abilities for different yield related traits such as ear per plant, row of kernels per ear, number of kernels /row ear length, days to maturity, ear diameter, 100 grains weight and grain yield per plant. The results revealed that the line A545 was the best general combiner and WFTMS $\times$ PB77 showed highest SCA for most traits that were under study.

On the basis of per se, sca and standard heterosis under induced moisture stress, the hybrids $\mathrm{L}_{5} \times \mathrm{T}_{4}$ (plant height, root dry weight), $L_{1} \times T_{2}$ (number of kernel rows and cob length), $\mathrm{L}_{4} \times \mathrm{T}_{4}, \mathrm{~L}_{6} \times \mathrm{T}_{3}$ (cob weight, cob length, number of kernels per row and grain yield), $\mathrm{L}_{3} \times \mathrm{T}_{2}, \mathrm{~L}_{3} \times \mathrm{T}_{4}$ (cob weight, cob length, single plant yield) were found to be superior and were recommended for heterosis breeding programme (Table 3,4). The ratio of $G C A$ : $S C A$ variances worked out for various traits showed that SCA variances were greater than GCA variances indicating the predominance of non-additive gene action for all the traits for both the conditions. Wali et al., (2010) reported that GCA effects was less than the SCA effects for kernels per row and 100 grain weight and reported the predominance of non-additive gene effects for inheritance of these traits in maize. Sain dass et al., (1998) stated that both additive and non-additive genetic variance were important in the expression of yield, for which they noted the hybrids separately. But in the present study, the expression of grain yield was mostly governed by non-additive gene action which was pronounced with the identification of more number of heterotic hybrids with significantly positive $s c a$ effects.

Based on the results, the hybrids L2xT1 (VIM $61 \times$ VIM 236), L3xT2 (UMI 1200 x VIM 93), L3xT4 (UMI 1200 x VIM 153), L4xT4 (VIM 244 x VIM153), L6xT3 (VIM108 x VIM 418) (Table 3, 4) were found to be desirable for yield/plant and most yield components under drought. The hybrids L3 x T4 recorded positively significant values for grain yield and considered as the best hybrid for both the conditions. The results of the study revealed that the identified hybrids showed desirable heterotic levels for yield and drought parameters that are desirable in areas with marginal rainfalls and could be utilized in maize breeding programs.

\section{References}

Barrs H.D and Weatherly, P.E. 1962. A reexamination of relative turgidity for estimating water deficit in leaves. Aust. J. Biol.Sci., 15: 413 - 428

Bolanos, J. and Edmeades, G. O. 1996. The importance of the anthesis-silking interval in breeding for drought 
tolerance in tropical maize Field Crops Research 48: 65-80.

Bruce, W.B., G.O. Edmeades and Barker, T.C. 2002. Molecular and physiological approaches to Maize Improvement for Drought Tolerance. Journal of Experimental Botany, 53, 13-25.

CIMMYT, 2000. World maize facts and trends report. Pp.45-47

Sain Dass., P. Arora and Singh.M. 1998. Genetics of grain yield and cob trait in maize. Ann. of Bio, 13 (2): 283-287.

Edmeades, G. O., J. Bolanos, A.Elings, J.Ribaut, M.Banziger and Westgate, M.E. 2000. The role and regulation of the anthesis-silking interval in maize. In Physiology and modeling kernel set in maize, Vol. 29

Fu, F.L., Z.L. Feng, S.B. Gao, S.F. Zhou and Li, W.C. 2008. Evaluation and Quantitative Inheritance of Several Drought-Relative Traits in Maize. Agricultural Sciences in China, 7, 280290.

IRRI, 1996. International network for genetic evaluation of rice. Standard evaluation system for rice. IRRI, Los Banos, Philippines.

Maazou, A.R.S., J.L. Tu, J.Qiu and Liu, Z.Z. 2016. Breeding for Drought Tolerance in Maize (Zea mays L.). American Journal of Plant Sciences, 7, 1858-1870.

Moser, S.B., B. Feil, S. Jampatong and
Stamp, P.2006.Effect of preanthesis drought, nitrogen fertilizer rate and variety on grain yield, yield components and harvest index of tropical maize. Agricultural water management, 81:4158

Olaoye, G., A.Menkir and Jacob S.J. 2009. Evaluation of local maize (Zea mays L.) varieties from Burkina faso as source of tolerance to drought. J.Appl.Biosci, 17:887-898.

Nouman, M. 2012. Combining ability estimates for grain yield and its components in maize (Zea mays L.). M. Sc. Thesis Dept. Plant Breed. \& Genet. Univ. Agri. Faisalabad

Ribaut, J.M., J. Betran, P. Monneveux and Setter, T. 2009. Drought Tolerance in Maize. In: Bennetzen, J. and Hake, S., Eds., Handbook of Maize: Its Biology, Springer, New York, 311-344.

Saglam, A., A. Kadioglu, M. Demiralay and Terzi, R. 2014. Leaf Rolling Reduces Photosynthetic Loss in Maize Under Severe Drought. Acta Botanica Croatica, 73-2.

Wali, C.M., R.M. Kachapur, C.P. Chandrashekar, V.R. Kulkarni and Devaaranavadagi, S.B. 2010. Gene action and combining ability studies in single cross hybrids of maize (Zea mays L.). Karnataka J. Agric.Sci., 23:557562.

\section{How to cite this article:}

Kumari Vinodhana N. and Ganesan K. N. 2017. Analysis of Physico-Genetic Traits for Drought Tolerance in Maize (Zea mays L.). Int.J.Curr.Microbiol.App.Sci. 6(7): 4568-4575. doi: http://dx.doi.org/10.20546/ijcmas.2017.607.477 